\title{
Social Condition of Paris during French Revolution as Reflected in Charles Dickens' a Tale of Two Cities
}

\author{
Ichsan Rahmad, Ari Setyawan \\ Ichsanrasetyawan@gmail.com \\ English Education Department - STKIP Al Amin Indramayu
}

\begin{abstract}
The objectives of the study are to describe the social condition of the novel and the other sources and to analyze the novel by means of sociological aspect to know the social condition in Paris during the French revolution in the novel A tale of Two Cities by Charles Dickens, focusing on the portrait of social condition in Paris. The methods used in this research are observation and documentation. The research findings are; first, there are injustice conditions before the revolution have done by the aristocrats such as politic, economy, oppression, and so on which have to face by the citizens. Second, all the injustice has done by aristocrats made social disappointment and led to revolution. Third, the government, even in absolute monarchy term, could be ruined by united people in the same purpose; they wanted better change for their country.
\end{abstract}

\section{Keywords: Charles Dickens, A Tale of Two Cities, Sociological, Paris}

\section{INTRODUCTION}

According to Bustami Subhan (Subhan, 2006:15) literature is a branch of artwork which is using language as media to express idea, thought, feeling, and experience to educate and also entertain reader or audience. Literature reflects many sides, and those are very interesting to be analyzed through approaches. One of the approaches is sociological approach. Literature is an expression of society (Wellek, 1956: 83). This is an approach to analyze the social background of the period of the certain classic novels. A certain experience of the author that contains sociological matter is taken as main source to his or her literary work. Thus, this is a transferred interaction that is produced by author himself or herself into the product that is called literary work.

When author is being a part of the society his or her literary work, he or she create the reflection of his or her part in society into their literary work. An author is a human being, they are social creature, and they are interacting and connecting naturally with every aspect in his or her society. Thus, authors are very influenced by their social background experience, such as social problems, religious beliefs, and culture.

Art does not merely reproduce life but also shape it (Wallek, 1956:90), an author not only influenced by society, but also an author influences the society. In this case, every moments experienced by author, include people behavior which occur in author's social life gives very much help in reflecting issue and inspiration in creating a literary work. Literary work is not only a product or result of social dynamic but also can be a cause in social development (Levin, 1973), in other hands, literary work brings and provides social and cultural phenomena which happen in author's real life. 
The writer wants to describe and lead the reader to imagine the social condition and problem which were faced by the society during the revolution in the eighteenth century. In order to know the social condition occurred in A Tale of Two Cities the writer uses Sociological Approach, in this study the writer encourages to give a title: "Social Condition of Paris during French Revolution"

\section{LITERATURE REVIEW}

\section{A. Sociological Meaning}

Sociology first came from $19^{\text {th }}$ century by French philosophies Auguste Comte, he Wrote many books about general approach to study society. He suggested that all researches about society to be organized into one branch of scientific social study which is independently stood (Soekanto, 1990:4). The name given in that time is "Sociology" (1839) came from latin word "Socious" meaning "friend" and from Greek "logos" meaning "word" or "talking" (soekanto, 1990:4) It means that sociological study is a study about society or social culture. The more detail explained by The American Sociological Association (2006), describes sociology as the study of social life, social change, and the social causes and consequences of human behavior. According to Barkan (1997:4), "society profoundly shapes their behavior and attitudes". We exist within social structure, which refers to pattern of social interaction and social relationships. Social structure in turn, has great influence on which we are as individuals. It influences our behavior, attitude and life chances. Social structure is complex and often contradictory.

In relation from sociology of literature, Wellek and Warren (in Subhan, 2006:80), explain that sociology of literature is divided into three branches. First, sociology of literature which only studying the author, that is discussing sociology of the author which consist of author ideology, author point of view, and author social status in relation as the creator of the literary work. Second, sociology of literature analyzes sociology of universe or sociology of society. In this branch of sociology, social phenomena, social change and social condition are the main topic of literary work and need to be discussed deeply. Last, sociological of the reader, in this branch the problem discussed are: (1) the kind of readers, (2) readers critic and reaction of literary works, and (3) the advantage of reader after reading the literary work. And the conclusion of all, sociology is the study about human behavior, which the behavior creates attitude, culture, phenomena and other social condition in human society.

\section{B. Sociology of Literature}

According to Bustami Subhan (Subhan, 2006:15) literature is a branch of artwork which is using language as media to express idea, thought, feeling, and experience to educate and also entertain reader or audience.

Literature is an expression of society (Wellek, 1956:83). This is an approach to analyze the social background of the period of the certain classic novels. A certain experience of the author that contains sociological matter is taken as main source 
to his or her literary work. Thus, this is a transferred interaction that is produced by author himself/herself into the product that is called literary work

In relation to the study, sociology of literature is a new approach or method to analyze or critic literary works. This approach is about the author and the condition of his social life as an author is being the part of the society. In this case, A Tale of Two Cities created by phenomena which is happened in two cities, Paris and England. And the author himself was being part of it. According to Leenhardt in International Social Science Journal (Unesco, 1967) sociology of literature covers two very different type of research, bearing reflectively on literature as consumer product and literature as an integral part of social reality or considered from other angle, bearing on society as the place of literary consumption and society as subject of literary creation.

\section{French Revolution}

Great France Revolution was a radical and social political upheaval period in European, especially in France. There were some factor that caused the revolution, from social injustice to absolute monarchy. (Godechot, 1989:34-36) mentioned the factors are:

1. The deceasing of the income in the country

2. The development of the French's intellectuality

3. The monopoly of authority by the noble

The French Revolution made big impact in all aspect of life such as Economic aspect, politic aspect, social aspect and religious aspect (Godechot, 1989:53-62).

\section{RESEARCH METHOD}

\section{A. Type of the Study}

The study is categorized into library research, since all data sources are taken from library. There are primary and secondary source. The primary source is the novel A Tale of Two Cities by Charles Dickens, the secondary is some books related to the social condition in the novel and from internet websites

1. Subject of the research

The subject of the research is the novel A Tale of Two Cities by Charles Dickens 2. The Object of the Research

The object of the research is the Condition of Europe in $! 8^{\text {th }}$ Century as reflected in Charles Dickens' A Tale of Two Cities. 


\section{B. Data Collecting Method}

Data collecting method is the way which is used by researcher to obtain the data. It is employed to collect the data by critical reading and documentation. The writer reads the major source of the research seriously and carefully. Then, the researcher observes and takes notes. The notes that researcher takes are arranged as documentation fo further analysis. The researcher uses the documentation data as reflected in the novel from the book and internet source. The data in the research are collected through library method.

\section{Data Analyzing Method}

The collected data are analyzed by using descriptive qualitative method and sociological approach. It is a technique which is stated by statements, or sentences, or described by explanation. It is used to give the clear description about the study qualitatively choosing, considering, defining and arranging the fixed data. After the data are collected, they are classified according to the subject to be discussed. The researcher tries to provide clear information and describes the condition of Eureope in the $18^{\text {th }}$ century as reflected in A Tale of Two Cities. Then the data are analyzed and interpreted by using sociological approach to reveal the novel.

\section{FINDINGS AND DISCUSSIONS}

\section{A. Injustice}

Kings in both countries was surrounded by greedy lords, corrupt church and ladies preferred to look after themselves rather than their people and made their rules and policies that only benefit themselves. The condition of social injustice can be seen through the quotation of Mercier (in Sara Ferry):

In the morning he has preached. let us say, against luxury in dress... In the evening, however, one of those he has denounced stations herself at his request in the church, scandalously and abominably arrayed. and takes toll of the faithful. (Sara Ferry, 2011:7)

And the quotation of social injustice in the novel that shows injustice did by church or king relatives can be seen below:

with such humane achievements as sentencing a youth to have his hands cut off, his tongue torn out with pincers, and his body burned alive, because he had not kneeled down in the rain to do honors to a dirty procession of monks which passed within his view (TTC: 10$)$

The quotation above indicates that a government or church as a part of government's department which is ruled by king relative family and for those who work with, did not take care about the people. they made foolish rule and policy that only have benefit for themselves. 


\section{B. Economy}

Dickens described the social economy distinction of French and England in eighteenth century, like the government that ruled by noblemen became the highest class and enjoyed the high prosperity which gotten from high paid taxes and have forgotten their people. Like the citizens' rights and taxes that must be paid during the industrial revolution in England. The conditions stated in the quotation of Sydney Smith (in Hartwell):

Taxes on everything on earth and the waters under the earth - on everything that comes from abroad, or is grown at home - taxes on the raw material-taxes on every fresh value that is added to it by the industry of man. (Hartwcll. 1981: 129)

The people of France economical condition before revolution was as suffer as England; many peasants have small scale of field, and they only had few amount of harvest, and forced to be Laborer or even beggar. it can be seen in Henri See's quotation from his book:

Many peasants possessed only infinitesimal parcels of land, particularly in northern France. Lefebvre proves that in Cambrésis from 60 to 70 per cent of the owners held less than a hectarc, and 20 per cent less than five hectares. But since at least five hectares are necessary to support a family, most of the peasants had to find work as farmers or as agricultural laborers. In Flanders. Cambrésis, and Hainault. as well as in Artois. Picardy, and Normandy, and to a certain extent in Brittany. there was a veritable rural proletariat which was reduced to misery by lack of work or poverty, and that explains the great number of beggars and vagabonds. Owners of means and farmers on a large scale (often called laboureurs) constituted only a small minority of the rural population. It was especially this class that, at the time of the Revolution, profited by the abolition of the manorial system and the sale of the national property. (Henri See, 2004:12)

Dickens criticized the uncared and injustice between top class and lower class in society in the quotation:

Expressive signs of what made them poor, were not wanting; the tax for the state, the tax for the church, the tax for the lord, tax Local and tax general. were to be paid here and to be paid there. (TTC: Ill)

All these things, and a thousand like them, came to pass in and close upon the dear old year one thousand seven hundred and seventy-five. Environed by them, while the Woodman and the Farmer worked unheeded, those two of the large jaws, and those other two of the plain and the fair faces, trod with stir enough and carried their divine rights with a high hand. Thus did the year one thousand seven hundred and seventy-five conduct their Greatnesses, and myriads of small creatures - the creatures of this chronicle among the rest-along the roads that lay before them. (TIC: 11) 
The quotation above indicates there are many social distinctions between classes in eighteenth century. Woodman and farmer who are the part of lower class, worked hard, and paid less, while government noblemen enjoyed prosperity from taxes they got from lower class without caring and paying attention on lower class like woodman and the farmer.

\section{Politic}

The political condition of France in eighteenth century was ruled by intellectual people, like the high classes of the society. They are king relatives, noblemen, or people who work with government. With those intellectual rights. they fooled the lower class with arbitrary policy; Mercier (in Sara Ferry) says:

The citizen of the capital has never given a thought to his political importance. His kings rule as they please. their caprices move him only to occasional and childish outbreaks against their authority; he is neither altogether free, nor wholly a slave. (Sara Ferry, 2011:8)

The one of the factors of French revolution is the rise of intellectual; the French Revolution of 1789 was a war for intellectual principles. Dickens has said it was the inevitable and logical rising of an extremely intelligent nation against the farcical incompetence of the rule of the kings. The government cannot recover the politic situation and makes the unsatisfied of the people like the woodman. farmer, and the middle class for a say in the government of the country. The ruler of countries, the king or quee were the same. This condition can be seen in the following quotation:

What L have been thinking as we came along, and what 1 am still thinking now, as I look into your kind strong face which gives me so much support1 is this:- If the Republic really does good to the poor, and they come to be less hungry, and in all ways to suffer less, she may live a long time: she may even live to be old. (TTC: 376)

The words the quotation above states a young woman about to be beheaded testify to the good which still remains in the people of France. The fact that she's able to imagine a future based upon the injustice of her own death becomes a sort of sublime hope for a time that will eventually see an end to violence. The violence, injustice, can only be stopped by revolution, with the united of all people of France and the united thought of people of France in the same movement can be seen in the quotation:

What private solicitude could rear itself against the deluge of the Year One of Liberty--the deluge rising from below, not falling from above, and with the windows of Heaven shut, not opened! (TIC: 276) 
The term of "Libcity" becomes blind to the struggles and the rig) $1 \mathrm{~s}$ of Individuals. As everyone tells Doctor Manette, individual sacrifices for the good of the Republic should be welcomed - even if those sacrifices include the unfair execution of family members.

\section{Oppression}

The aristocrats or noblemen at the moment always oppress the lower class and made such a suffering condition, the noblemen ruled many lands or fields. and worked farmer or peasant to manage their field, but the peasant only paid less for that, and got less from the harvest, the rest taken by noblemen. Henry see states the condition of the land management between England and France that oppress peasant like below:

Finally the aristocracy, which had seized the political power as a result of the revolutions during the seventeenth century, was free to take possession of all the land. In France it was quite different. Commercial and industrial capitalism was slower to develop and less intense. The lords were increasingly submitted to the authority of the crown, which opposed excessive encroachments. Furthermore, since they enjoyed extensive manorial rights that were often lucrative, the nobles did not care to destroy the system of peasant tenures depending upon their fiefs. Thus small peasant ownership perhaps owes its continued existence and its progress to the maintenance of the manorial system. (Henry See, 2004:13)

The lower class had been the victims of government policy and noblemen arbitrary. This condition written in dickens' following quotation:

Monseigneur, the good God knows; but 1 don't ask it. My petition is, that a morsel of stone or wood, with my husband's name, may be placed over him to show where he lies. Otherwise, the place will be quickly forgotten. it will never be found when I am dead of the same malady, I shall be laid under some other heap of poor grass. MonseigneUr, they are so many. they increase so fast, there is so much want. Monscigneurl Monseigneur!'(TTC: 120-121)

The valet had put her away from the door, the carriage had broken into a brisk trot, the postilions had quickened the pace, she was left far behind. and Monseigneur, again escorted by the Furies, was rapidly diminishing the league or two of distance that remained between him and his chateau. (TT C: 12 1)

From the quotation above indicates that noblemen is the top in the class, have power and authority and could do whatever they want to the lower class, even to oppress them with their authority. Because of the rules and policy made by king with his government. it made policy that did not care the people and not give any attention to them but people must obey the rules. 


\section{E. Crime, robbery and theft}

The eighteenth situation in both countries were very compliment and hard. The robbery and theft in the novel made discomfort situation; it made people felt insecure in their daily life. This happened because of the rules by government and oppression by noblemen which did not care the people, and made people live in poor life and sorrow, which made them to do robbery and theft. The description of the crime in the eighteenth century can be seen from the quotation by M. Beloff (in E. P. Thompson):

l'his resentment, when unemployment and high prices combined to make conditions unendurable, vented itself in attacks upon corn-dealers and millers, attacks which often must have degenerated into mere excuses for crime. (E. P. Thompson: 76)

The condition of the hard situation in Paris in eighteenth century in the novel can be seen in the following quotations:

Daring burglaries by armed men, and highway robberies, took place in the capital itself every night; families were publicly cautioned not to go out of town \#ithout removing their furniture to upholsterers' warehouses for security; (TTC: 10)

Thieves snipped off diamond crosses from the necks of noble lords at Court drawing-moms; musketeers went into St. Giles's, to search for contraband goods, and the mob fired on the musketeers, and the musketeers fired on the mob, and nobody thought any of these occurrences much out of the common way.(TTC: 11)

The quotation above, states that the condition made by noblemen oppression treatment that made people to do robbery and theft, because they are hungry and suffered. It made them to do so.

\section{F. Hunger}

Condition of Europe in eighteenth century was very dreadful, hunger everywhere, they are low class, farmer, woodman, laborers, etc. they were even hungered at corn-field where they Worked; E. P. Thompson describes this condition below:

In the I 790s the gentry themselves were somewhat perplexed. Sometimes crippled by an excess of rich food, the magistrates from time to time put aside their industrious compilation of archives for the disciples of Sir Lewis Namier, and peered down from their parklands at the corn-fields in which their labourers hungered. (E. P. Thompson: 136)

The condition of poor people in both country were same, they must pay high taxes while their revenue paid slightly. It made many people in starving condition, 
while the people of both country starving, the king and his family live in clover and eat well, the condition of starving people can be seen in quotation below:

And upon them, and upon the grown faces, and ploughed into every furrow of age and coming up afresh, was the sigh, Hunger. It was prevalent everywhere. Hunger was pushed out of the tall houses, in the wretched clothing that hung upon poles and lines; Hunger was patched into them with straw and rag and wood and paper; Hunger was repeated in every fragment of the small modicum of firewood that the man sawed off; Hunger stared down from the smokeless chimneys, and started up from the filthy street that had no offal, among its refuse, of anything to eat. Hunger was the inscription on the baker's shelves, written in every small loaf of his scanty stock of bad bread; at the sausage-shop, in every dead dog preparation that was offered for sale. Hunger rattled its dry bones among the roasting chestnuts in the turned cylinder; Hunger was shred into atomics in every farthing porringer of husky chips of potato. fried with some reluctant drops of oil. (TTC: 35-36) What I have been thinking as we came along, and what I am still thinking now, as I look into your kind strong face which gives me so much support, is this:- If the Republic really does good to the poor, and they come to be less hungry, and in all ways to suffer less, she may live a long time: she may even live to be old.'(TTC: 376)

The quotation above can be seen that many poor people die for the condition was very poor, people died because government did not take care of them, so they suffer poor and hungry.

\section{CONCLUSSIONS}

After analyzing Charles Dickens' A Tale of Two Cities through sociological approach ad based on the research finding in the discussion chapter, the researcher finally writes the conclusion as follows:

a. Saint Antoine is a suburb of Paris, refers to the king Lois' XVI empress Marie Antoinette, who was the one of the French Revolution causes. She wasted kingdom's money and made the country fell into bankruptcy.

b. Bastille stormed by democrats and republicans against absolute monarchy in 14 July 1789 during the French Revolution.

c. Aristocrats and monks are the highest social class in Paris, while peasants, farmers and woodmen are the lowest class.

d. Jacques in the novel A Tale of Two Cities refers to the code name for Revolutionaries in French revolution history.

e. The assassination of Marquis St. Evermonde and aristocrats in the novel A Tale of Two Cities represents the murder of aristocrats in French history such as like aristocrat commander Marquis Bernard-Rene de Launay, Governor of Bastille. 


\section{SUGGESTIONS}

Based on the analysis the researcher gives some suggestions for the readers and those may be useful for the readers.

a. By reading the literary works such as novel, the readers will get some knowledge such as the way of life, idealism, history, and culture. In other hand, it also will enrich the readers' skill in the English vocabulary, grammar, and pronunciation.

b. The researcher expects the readers to learn history. The social condition, problem, and phenomenon that happened in the past history, can appear again, because history is continual; it always happens even though it happens in different places and time.

\section{REFERENCES}

Sardjono, Soekanto. 1990. Sosiologi Suatu Pengantar. Jakarta: Rajawali Press.

Solaeman, M Munandar. 2000.11mu Sosial Dasar. Bandung: Refika Aditama.

Dickens, Charles. 1960. A Tale of Two Cities. New York: The New American Library of World Literature, Inc.

Subhan, Bustami. 2006. Understanding Literary Appreciation. Yogyakarta: Debut Press.

, 2010. Literary Criticism. Yogyakarta: Debut Press.

Pospelov, G.N. 1967. Literature and Sociology. Paris: Unesco.

Wellek, Rene and Austen Warren. 1956. Theory of Literature. New York: Harcourt, Brace and World, Inc.

Leenhardt, Jacques. 1967. The sociology of literature: some stages in its history. Paris: Unesco.

Godechot, Jacques. 1989. Revolusi di Dunia Barat (1770-1799). Yogyakarta: Gadjah Mada University Press.

Hartwell, Ronald Max. 1981. Taxation in England During Industrial Revolution. USA: Cato Institute.

Hadi, Sutrisno. 1984. Methodology Research. Yogyakarta: Fakultas Psikologi UGM.

Hornby, A.S. 1962. Oxford Advanced learner's dictionary of Current English. Great Britain: Oxford University Press. 
WEJ, Vol 2 No 1 September 2018

Soemardjan Selo and Soelaeman Soemardi. 1964. Setangkai Bunga Sosiologi. Jakarta: FEUI.

Barkan, Steven E. 1997. Crinminology: A Sociological Understanding. Upper Saddle River: Prentice Hall.

See, Henri. 2004. Economic and Social Conditions in France during the Eighteenth Century. Canada: Batoche Books.

Thompson, E. P. 1966. The Moral Economy of the English Crowd in the Eighteenth Century. USA: Department of History.

McGraw-Hill. 2004. The Transformation of the English Monarchy: Civil War and Revolution. USA: The Annenberg Foundation.

Haferkamp, Hans and Neil J. Smelser. 1992. Social Change and Modernity. USA: University of California Press.

Le Bon, Gustave. 2001. The Psycholou of Revolution. Canada: Batoche books.

O'cinneide, Colm. 2008. The Right to Equality: A Substantive Legal Norm or Vacuous Rhetoric?. From http://www.uclshrp.com/review, 22 December 2011.

Ferry, Sara E. 2011. Paris on the Eve of Revolution. From http://web,mit.edu/ , 22 December

Internet sources:

http://www.sparknotes.com/lit/twocities/summary.html

http://www.dickens-literature.com/l biography.html

http://www.asanet.org 